\title{
Angiotensin II's Antiproliferative Effects Mediated Through AT2-Receptors Depend On Down-Regulation of SM-20
}

\author{
Gunter Wolf, Sigrid Harendza, Regine Schroeder, Ulrich Wenzel, Gunther Zahner, \\ Ulrike Butzmann, Robert S. Freeman, and Rolf A. K. Stahl
}

Department of Medicine (GW, SH, RS, UW, GZ, UB, RAKS), Division of Nephrology and Osteology, University of Hamburg, Hamburg, Germany; and Department of Pharmacology and Physiology (RSF), University of Rochester School of Medicine and Dentistry, Rochester, New York

\begin{abstract}
SUMMARY: Angiotensin II (ANG II) inhibits proliferation and induces differentiation through AT2 receptors. However, target genes involved in this process are not well characterized. We studied PC12 cells, a rat pheochromocytoma cell line exclusively expressing AT2 receptors. ANG II attenuated proliferation of PC12 cells without concomitant induction of apoptosis. To identify potential novel genes involved in the antimitogenic actions of ANG II, we performed differential display analysis of PC12 cells after challenge with $10^{-7}$ M ANG II for 6 hours. One identified gene selected for further study that was down-regulated by ANG II in PC12 cells was SM-20. This gene has been previously isolated from vascular smooth muscle cells treated with mitogens by differential hybridization. Recent findings show a homology of SM-20 with enzymes involved in the regulation of hypoxia inducible factor 1. ANG II suppressed mRNA expression of SM-20 in PC12 cells after only 30 minutes, as detected by Northern blotting. This effect was antagonized by an AT2 receptor blocker, but not by losartan. A rabbit polyclonal antibody was generated against a peptide sequence of SM-20 and detected a major band of the predicted size of $40 \mathrm{kd}$ and a second 33-kd band that likely represents a processed form present in mitochondria. Immunohistochemistry revealed a granular staining of the cytoplasm of PC12 cells compatible with a previously described mitochondrial localization of SM-20 protein. Western blots confirmed the down-regulation of SM-20 protein in PC12 cells subsequent to incubation with ANG II. SM-20 transcripts were also reduced by ANG II acting on AT2 receptors in rat glomerular endothelial cells that express both AT1 and AT2 receptors. SM-20 antisense, but not sense, phosphothioate-modified oligonucleotides reduced base-line proliferation of PC12 cells. In contrast, inducible overexpression of SM-20 using the ecdysone system prevented the antiproliferative effects of ANG II in PC12 cells. In summary, our study identified SM-20 as an essential component of ANG Il's growth-suppressive effects mediated through AT2 receptors. This gene apparently plays an important role in the regulatory processes determining whether a cell should undergo differentiation, apoptosis, or proliferation. (Lab Invest 2002, 82:1305-1317).
\end{abstract}

$A$ ngiotensin II (ANG II) induces growth stimulatory effects such as proliferation or hypertrophy in many cells (Katz, 1990; Wolf and Neilson, 1993; Woolfson and Fine, 1996). These effects are principally mediated through AT1-receptors, and several signal transduction cascades, including reactive oxygen radicals, and various protein kinases have been identified that link AT1-receptor activation to regulatory events of the cell cycle machinery. On the other hand, evidence accumulated in recent years demonstrates that binding of ANG II to AT2-receptors has opposite effects, including inhibition of proliferation and possible induction of apoptosis (Gallinat et al, 2000; Meffert

DOI: 10.1097/01.LAB.0000029207.92039.2F

Received April 9, 2002.

The present work was supported by grants from the Deutsche Forschungsgemeinschaft (Wo 460/2-4, 2-5, 8-1, 8-2).

Address reprint requests to: Dr. Gunter Wolf, Department of Medicine, Division of Nephrology and Osteology, University of Hamburg, University Hospital Eppendorf, Pavilion 61, Martinistr. 52, D-20246 Hamburg, Germany.E-mail:Wolf@uke.uni-hamburg.de et al, 1996; Stoll et al, 1995; Zimpelmann and Burns, 2001). However, potential genetic programs involved in this AT2-receptor transduced inhibition of proliferation are largely unknown (Matsubara, 1998). We used differential display analysis of mRNA obtained from PC12 cells, a pheochromocytoma cell line that exclusively expresses AT2-receptors (Kambayashi et al, 1993; Leung et al, 1992), after challenge with ANG II, to identify potential novel genes involved in growth inhibition. We found that SM-20, a previously characterized mitochondrial protein involved in apoptosis (Lipscomb et al, 1999, 2001; Wax et al, 1994, 1996), was down-regulated by ANG II. This suppression of SM-20 plays a critical role in ANG II-mediated inhibition of proliferation through AT2-receptors.

\section{Results}

\section{Effect of ANG II on Proliferation and Apoptosis of PC12 Cells}

We first tested whether ANG II inhibited proliferation in our batch of PC12 cells. As shown in Table 1, a single dose of $10^{-7}$ M ANG II for 24 to 48 hours significantly 
Table 1. Time Course of ANG II's Inhibitory Effects on $\left[{ }^{3} \mathrm{H}\right]$ thymidine Incorporation into PC12 Cells

\begin{tabular}{lcc}
\hline & \multicolumn{2}{c}{ Counts } \\
& \multicolumn{2}{c}{ per minute $\times 10^{3}$} \\
\cline { 2 - 3 } & Without serum & $10 \%$ FCS \\
\hline Controls 24 hours & $6.0 \pm 0.4$ & $9.8 \pm 0.4^{* * *}$ \\
$10^{-7}$ M ANG II 24 hours & $4.5 \pm 0.2^{* *}$ & $5.9 \pm 0.6^{* *}$ \\
Controls 48 hours & $11.8 \pm 0.6$ & $10.3 \pm 0.6$ \\
$10^{-7}$ M ANG II 48 hours & $7.7 \pm 0.4^{* *}$ & $9.3 \pm 0.6^{*}$ \\
Controls 72 hours & $9.5 \pm 0.5$ & $12.4 \pm 0.6^{* \star *}$ \\
$10^{-7}$ M ANG II 72 hours & $7.7 \pm 0.6^{\star *}$ & $13.0 \pm 0.7$ \\
\hline
\end{tabular}

${ }^{*} p<0.05$ vs controls without ANG II; ${ }^{* *} p<0.01$ vs controls without ANG II; ${ }^{* \star *} p<0.05$ vs controls without FCS; $n=10$.

inhibited proliferation of cells grown in 10\% FCS. Inhibition of proliferation of PC12 cells by ANG II was also observed in the absence of serum and still occurred after 72 hours under this condition (Table 1). The anti-mitogenic effect was blocked by the AT2receptor antagonist PD123319, but not by the AT1receptor antagonist losartan (Table 2). Because it has been previously reported that AT2-receptor activation either stimulated or inhibited phosphotyrosine phosphatase (Brechler et al, 1994; Kambayashi et al, 1993) or, depending on the cell type, also induced serine/ threonine phosphatase 2a (PP2A; Huang et al, 1995; Kang et al, 1994), we inhibited phosphotyrosine phosphatase with orthovanadate and PP2A with okadaic acid in the absence and presence of ANG II. Okadaic acid stimulates basal proliferation and abolished the antimitogenic effect of ANG II (Table 2). In contrast, orthovanadate alone significantly inhibited base-line proliferation of $\mathrm{PC} 12$ cells, and even further reduced ANG II-mediated inhibition of mitosis (Table 2). In addition, ANG II also inhibited $\left[{ }^{3} \mathrm{H}\right]$ thymidine incorporation into $\mathrm{PC} 12$ cells in the absence as well as presence of $10 \%$ FCS (Fig. 1).

To test whether the ANG II-mediated inhibition of proliferation was actually caused by induction of apoptosis, DNA laddering experiments were performed. However, as demonstrated in Figure 2, $10^{-7} \mathrm{M}$ ANG II

Table 2. Effects of ANG II on Total Cell Number of PC12 Cells

\begin{tabular}{ll}
\hline & \multicolumn{1}{c}{ Cells } \\
& per well $\times 10^{3}$ \\
\hline Controls & $348 \pm 9.0$ \\
$10^{-7}$ M ANG II & $279 \pm 11.0^{*}$ \\
$10^{-6}$ M PD123319 & $321 \pm 12.0$ \\
ANG II + PD123319 & $331 \pm 18.0^{* *}$ \\
$10^{-6}$ M losartan & $368 \pm 16.6$ \\
ANG II + losartan & $256 \pm 16.9^{* *}$ \\
$10^{-7}$ M okadaic acid & $398 \pm 14.0^{*}$ \\
ANG II + okadaic acid & $336 \pm 16.2$ \\
$10^{-5}$ M orthovanadate & $262 \pm 5.9^{*}$ \\
ANG II + orthovanadate & $237 \pm 16.3^{*}$ \\
\hline
\end{tabular}

${ }^{*} p<0.05$ vs controls; ${ }^{* *} p<0.05$ vs ANG II only; $n=6$.

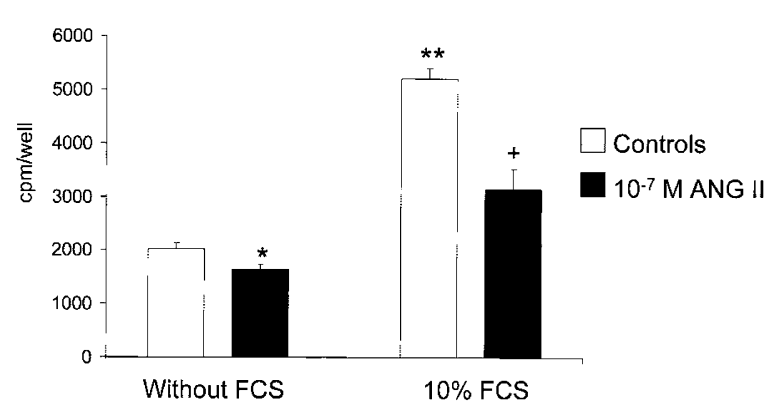

Figure 1.

Effect of a single dose of $10^{-7} \mathrm{M}$ angiotensin II (ANG II) for 24 hours on $\left[{ }^{3} \mathrm{H}\right]$ thymidine incorporation into PC12 cells. Cells were grown either without FCS or in medium with $10 \%$ FCS. ANG II inhibits proliferation in the presence and absence of FCS. ${ }^{*} p<0.05$ versus controls without $\mathrm{FCS},{ }^{*} * 0<0.01$ versus controls without FCS, ${ }^{+} p<0.01$ versus controls with $10 \% \mathrm{FCS}, n=$ 12; cpm, counts per minute.

for 24 hours did not induce cleavage of DNA. Apoptosis induced in PC12 cells by $50 \mu \mathrm{M}$ etoposide could easily be demonstrated with this assay (data not shown).

\section{Differential Display, Isolation, and mRNA Expression of SM-20}

To gain insight into genes that may be potentially associated with ANG II-mediated inhibition of proliferation, PC12 cells were stimulated for 6 hours with $10^{-7}$ M ANG II, and differential display analysis was performed using RNA isolated from cells grown in serum-free medium. A total of nine bands were isolated; two were up-regulated by ANG II treatment, whereas seven were suppressed by ANG II. Figure 3 reveals one example of the differential display analysis. The band labeled with the arrow was cut out of the gel and sequenced. Searching GenBank with BLAST revealed that this 261-bp fragment showed a $100 \%$ homology in the 3' untranslated end to rat SM-20. This gene has been previously isolated from smooth muscle cells stimulated with growth factors (Wax et al, 1994). Northern blot analysis confirmed the downregulation of SM-20 in PC12 cells treated with $10^{-7} \mathrm{M}$ ANG II (Fig. 4). The 2.7-kb mRNA was already downregulated after 30 minutes of incubation with ANG II, remained suppressed after 6 hours, but again increased to base-line levels after 24 hours (Fig. 4). Densitometry and statistical analysis revealed that these changes were significant (controls: $1.00 \pm 0.00$, 5 minutes: $0.89 \pm 0.05,10$ minutes: $0.93 \pm 0.19,30$ minutes: $0.76 \pm 0.18^{\star}, 60$ minutes: $0.67 \pm 0.05^{\star \star}, 6$ hours: $0.72 \pm 0.06^{\star \star}, 24$ hours: $0.87 \pm 0.10$ relative to changes in SM-20 expression normalized to $18 \mathrm{~S} ;{ }^{*} p$ $<0.05,{ }^{* *} p<0.01$ versus controls; $n=4$ to 7 ). Similar results were obtained when a full-length rat SM-20 cDNA probe was used instead of the differential display fragment (not shown). Treatment with $10^{-6} \mathrm{M}$ of the AT2-receptor antagonist PD123319, but not the same concentration of the AT1-receptor blocker losartan, abolished the ANG II-induced down-regulation of SM-20 in PC12 cells, suggesting signal transduction through AT2-receptors (Fig. 5; controls: $1.00 \pm 0.00$, 


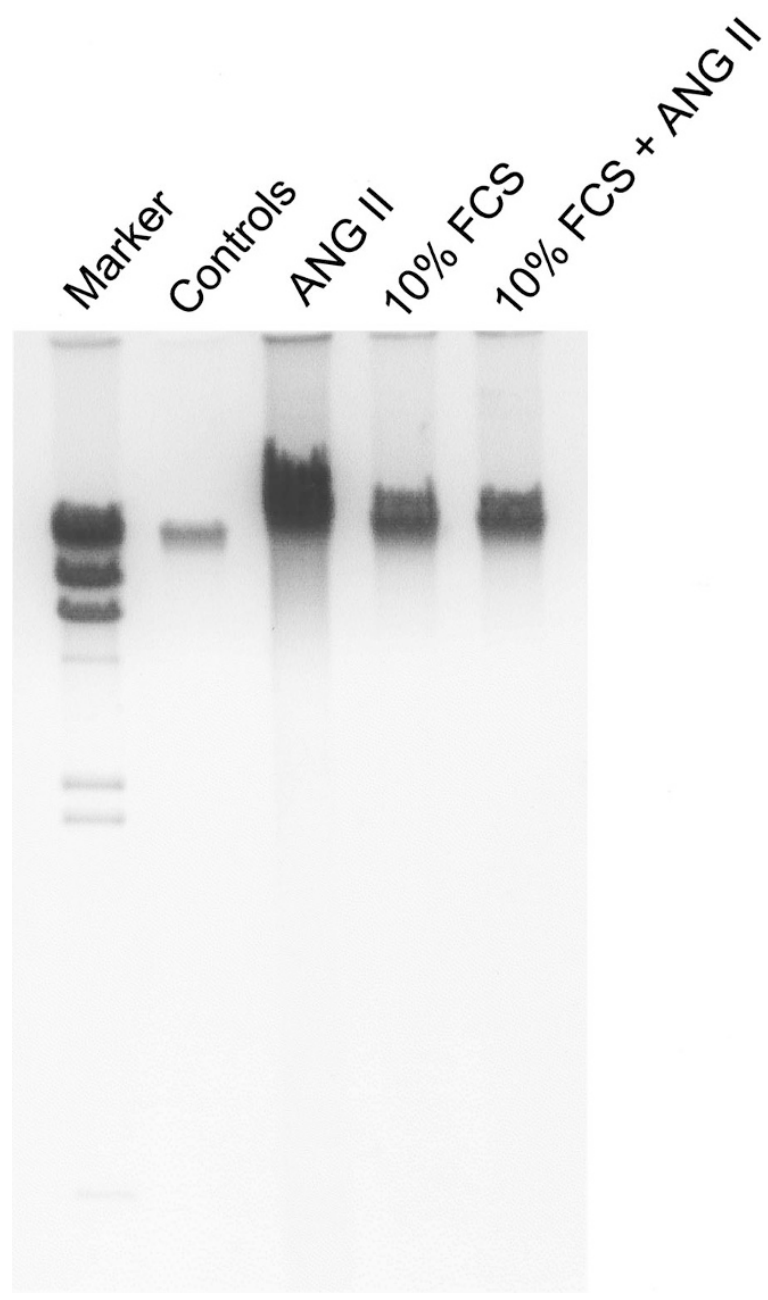

Figure 2.

DNA fragmentation to detect apoptosis. PC12 cells were stimulated for 24 hours with $10^{-7} \mathrm{M}$ ANG II in the absence (controls) or presence of $10 \%$ FCS (10\% FCS). Isolated DNA was size-fractionated on a $1 \%$ agarose gel and stained with ethidium bromide. However, only high molecular DNA is detected without the presence of DNA fragments, indicating the absence of apoptosis. This gel is representative of three independent experiments with similar results.

ANG I: $0.73 \pm 0.06^{\star *}$, ANG II + losartan: $0.61 \pm$ $0.08^{* *}$, ANG II + PD123319: $1.10 \pm 0.30$ relative to changes in SM-20 expression normalized to $18 \mathrm{~S}$; ${ }^{* *} p$ $<0.01$ versus controls; $n=3$ ). Cycloheximide (10 $\mu \mathrm{g} / \mathrm{ml}$ ) increased base-line SM-20 expression and abolished the ANG II-mediated reduction in PC12 cells (Fig. 6). Moreover, the broad specificity protein tyrosine phosphatase inhibitor orthovanadate completely suppressed base-line SM-20 expression in PC12 cells (Fig. 6). In contrast, the serine/threonine phosphatase inhibitor okadaic acid increased SM-20 base-line expression and prevented ANG II-mediated inhibition of SM-20 transcripts (Fig. 6).

To test whether SM-20 is also negatively regulated by ANG II in cells other than PC12 cells, a previously characterized rat glomerular endothelial cell line (GER) that expresses both AT1- and AT2-receptors was investigated (Wolf et al, 1996b). As shown in Figure 7, $10^{-7}$ M ANG II for 6 hours also suppressed SM-20
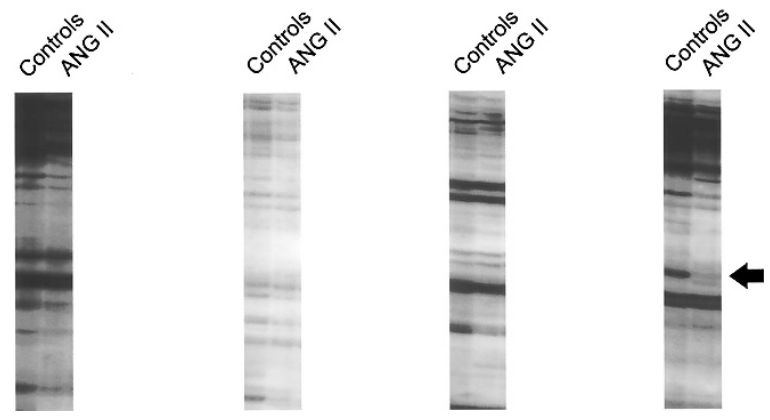

Figure 3.

Examples of differential display analysis of mRNA obtained from PC12 cells grown in serum-free medium in the absence (controls) or presence of $10^{-7} \mathrm{M}$ ANG II (ANG II) for 6 hours. Although most differentially expressed bands decreased after ANG II treatment, a few genes are up-regulated. The cDNA band labeled with the arrow was cut out of the gel and sequenced. It was 100\% homologous to SM-20.

SM-20

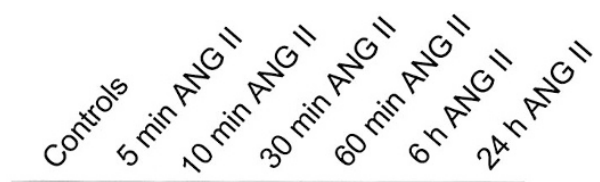

$18 \mathrm{~S}$
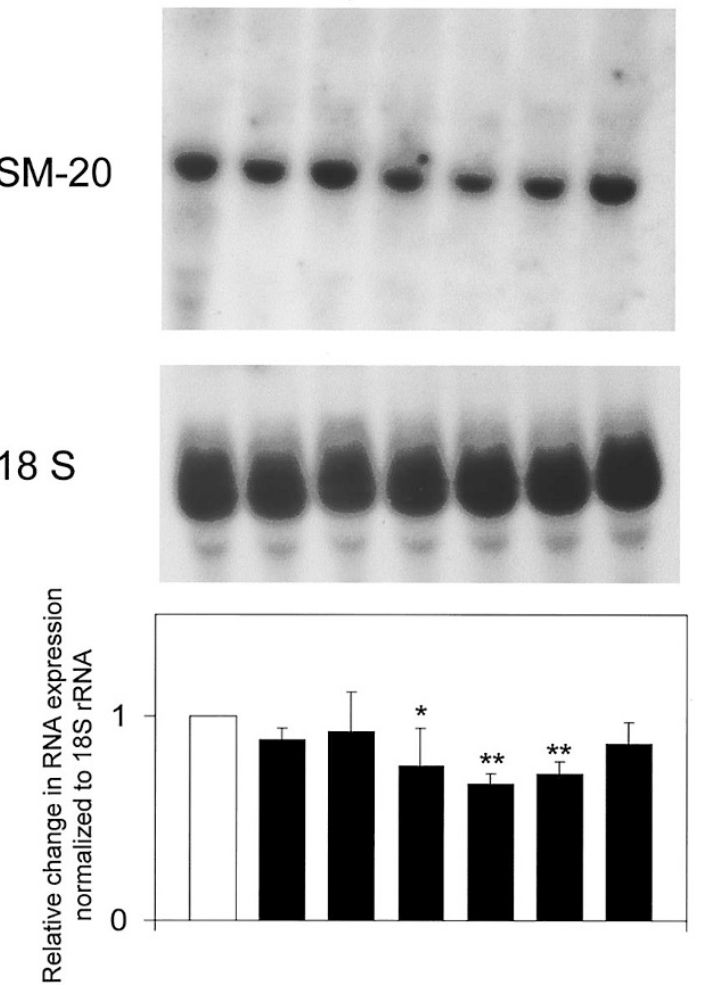

Figure 4.

Northern blot for SM-20. PC12 cells were stimulated in serum-free medium for up to 24 hours with a single dose of $10^{-7} \mathrm{M}$ ANG II. This treatment significantly reduces SM-20 expression after only 30 minutes. These blots are representative of four independent experiments.

mRNA in GERs. This effect was antagonized by $10^{-6}$ M PD123319, but not by coincubation with two different AT1-receptor antagonists (controls: $1.00 \pm 0.00$, ANG II: $0.66 \pm 0.15^{\star}$, ANG II + losartan: $0.46 \pm 0.18^{*}$, ANG II + irbesartan: $0.52 \pm 0.2^{*}$, ANG II + PD123319: $1.27 \pm 0.20$ relative to changes in SM-20 expression normalized to $18 \mathrm{~S}$; $\left.{ }^{*} p<0.05 ; n=3\right)$. We finally 

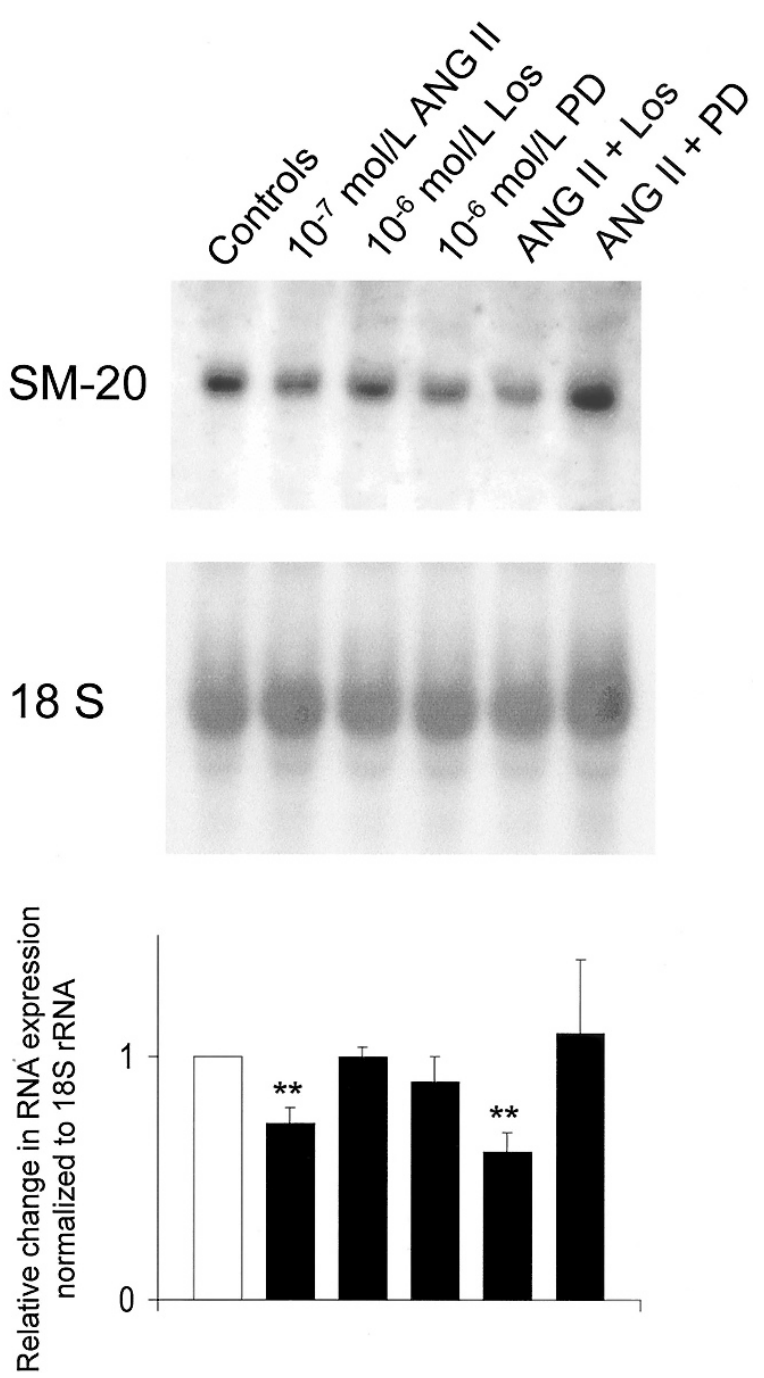

Figure 5.

Northern blot for SM-20 expression. The ANG II-mediated decrease in SM-20 transcripts in PC12 cells was completely abolished by $10^{-6} \mathrm{M}$ of the AT2 receptor antagonist PD123319 (PD), but not by the same concentration of losartan (LoS). These blots are representative of three independent experiments with qualitatively similar results.

selectively overexpressed AT2-receptors in COS7 cells that normally do not display receptors for ANG II. A single dose of ANG II $\left(10^{-7} \mathrm{M}\right)$ for 6 hours also reduced base-line SM-20 expression in these cells (Fig. 8; controls: $1.00 \pm 0.00$, ANG II: $0.60 \pm 0.10$ relative to changes in SM-20 expression normalized to 18 S; $p<0.05 ; n=3$ ). However, there was no SM-20 base-line expression in a mouse tubular and mesan-

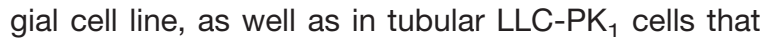
only express AT1-receptors (not shown).

\section{Characterization of an Antibody Against SM-20 and SM-20 Protein Expression}

To investigate whether the ANG II-mediated suppression of SM-20 mRNA in PC12 cells is paralleled by a reduction in protein, a polyclonal rabbit antibody was generated against a modified peptide encompassing amino acid sequence $331-346$ of SM-20 (CERAE-
AKKKFRNLTR), coupled with the N-terminal cysteine residue to keyhole limpet hemocyanin. Antiserum was purified with affinity chromatography. Preimmune serum obtained from the rabbit before immunization did not detect a specific band (Fig. 9A). Western blot analysis revealed that the anti-SM-20 antiserum detects a major band of approximately $40 \mathrm{kd}$ in PC12 cells lysates (Fig. 9A). This is in excellent agreement with the predicted size of the protein. In addition, a faint band slightly larger than $30 \mathrm{kd}$ can also be seen (Fig. 9A). This additional band likely corresponds to a previously described $33 \mathrm{kd}$ processed form of SM-20 lacking amino-terminal sequences that is predominantly present in mitochondria (Lipscomb et al, 2001). Addition of $10 \mu \mathrm{g}$ of the peptide used for immunization to the primary antibody almost completely abolished the detected bands, suggesting the specificity of the antiserum (Fig. 9A). Incubation of PC12 cells with $10^{-7}$ M ANG II for 12 hours reduced expression of SM-20 protein as measured by Western blot analysis of total cellular lysates (Fig. 9B, controls: $1.00 \pm 0.00$, ANG II: $0.72 \pm 0.10$ relative to expression of SM-20 normalized to $\beta$-actin; $p<0.05 ; n=3$ ).

Mitochondrial fractions were highly enriched to further study the distribution of SM-20. Mitochondrialrich fractions were identified through expression of the inner mitochondrial membrane-associated protein cytochrome c oxidase subunit IV (Cox 4; Fig. 10). Reincubation of the membrane with an antibody against cytochrome c (Cyto c) revealed strong expression in the mitochondrial fractions, but also some expression in cytoplasmatic fractions obtained from cells grown in the absence of ANG II (Fig. 10). In contrast, stimulation with ANG II reduced Cyto c expression in the cytoplasmatic fractions. This finding indicates that ANG II suppresses apoptosis rather than stimulating it. Western blotting of mitochondrial and cytoplasmatic fractions with the anti-SM-20 antiserum revealed only expression of the 33-kd band in mitochondria, whereas both bands are detectable in cytoplasmatic fractions (Fig. 10).

Immunohistochemistry using acetone-fixed PC12 cells revealed a granular cytoplasmatic staining with the polyclonal anti-SM-20 antibody (Fig. 11B). ANG II treatment apparently reduced the intensity of the staining (Fig. 11C). Replacement of the anti-SM-20 antibody with preimmune serum revealed no staining of PC12 cells (Fig. 11A).

\section{Effect of Inhibition or Inducible Overexpression of SM-20 on the ANG II-Mediated Antimitotic Effects in PC12 Cells}

To test the functional role of SM-20 in ANG IImediated inhibition of proliferation, PC12 cells were transfected with $1 \mu \mathrm{M}$ phosphothioate-modified SM-20 sense or antisense oligonucleotides. As shown in Figure 12, transient transfection of SM-20 antisense, but not sense, oligonucleotides reduced baseline $\left[{ }^{3} \mathrm{H}\right]$ thymidine incorporation. ANG II did not further reduce proliferation of $\mathrm{PC} 12$ cells transfected with antisense oligonucleotides compared with cells transfected with antisense alone (Fig. 12). Transfection with 


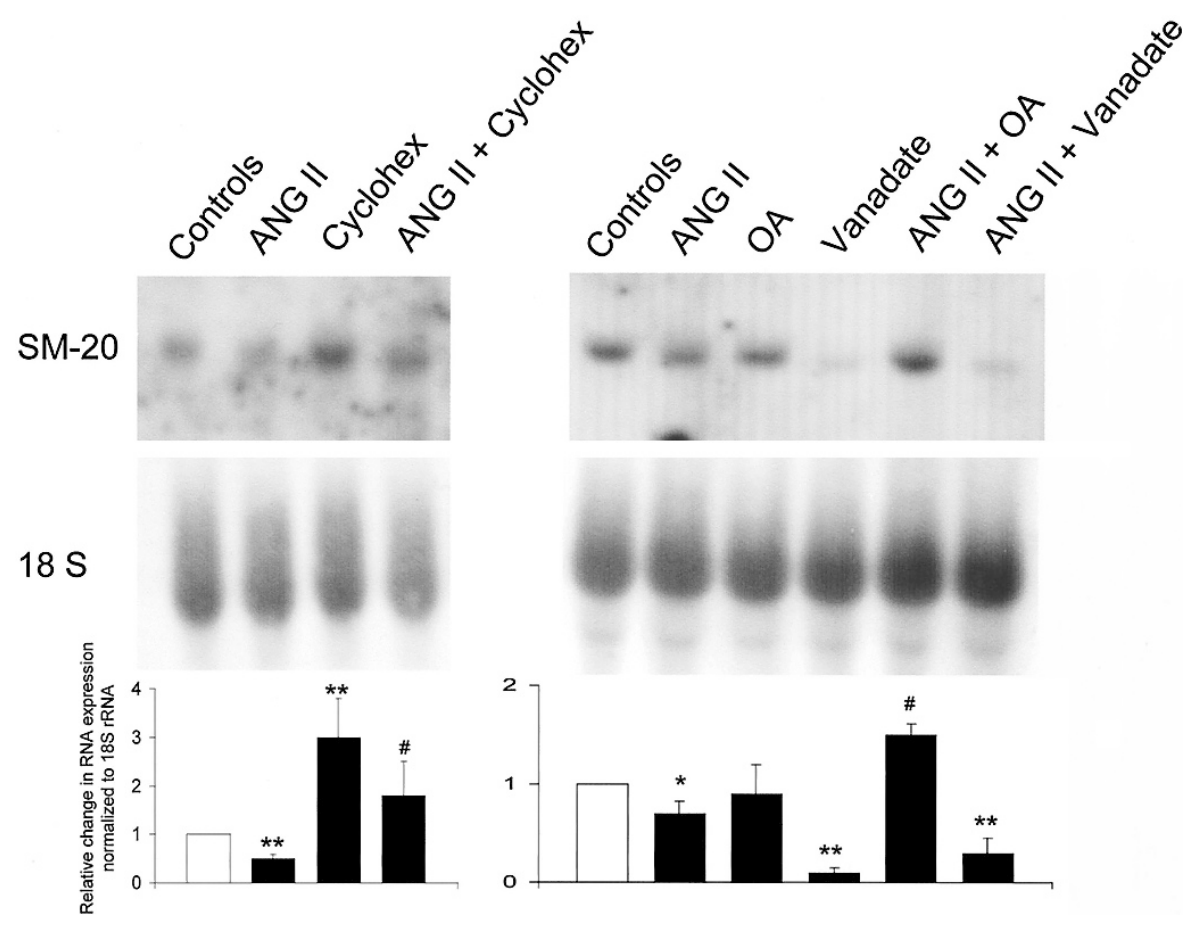

Figure 6.

SM-20 mRNA expression in PC12 cells. Left panel, Cycloheximide (cyclohex, $10 \mu \mathrm{g} / \mathrm{ml}$ ) induced SM-20 expression in cells grown in serum-free medium. Furthermore, cycloheximide also abolished the ANG II-mediated reduction in SM-20 transcripts. Right panel, The tyrosine phosphatase inhibitor orthovanadate (vanadate, $10^{-5}$ м) almost completely suppressed base-line SM-20 expression. ANG II did not further decrease this reduced expression. In contrast, the serine/threonine phosphatase inhibitor okadaic acid $\left(O A, 10^{-7} \mathrm{M}\right)$ inhibited the ANG II-mediated suppression of SM-20 mRNA, but did not stimulate expression in the absence of ANG II. These blots are representative of three independent experiments with qualitatively similar results. ${ }^{*} p<0.05$ versus controls; ${ }^{* *} p<0.01$ versus controls; ${ }^{*} p<0.05$ versus ANG II only.

SM-20 sense oligonucleotides did not influence the inhibitory effect of ANG II on $\left[{ }^{3} \mathrm{H}\right]$ thymidine incorporation (Fig. 12). SM-20 antisense oligonucleotides reduced SM-20 protein expression compared with transfection with sense oligonucleotides (Fig. 12).

SM-20 was cloned in the ecdysone-inducible expression vector pIND and was transiently cotransfected with pVgRXR. ANG ॥ $\left(10^{-7} \mathrm{M}\right)$ for 24 hours significantly reduced cell number in the absence of the inducer muristone (Fig. 13A). However, addition of 5 $\mu \mathrm{M}$ muristone attenuated the ANG II-mediated inhibition of proliferation in $\mathrm{PC} 12$ cell. $\left[{ }^{3} \mathrm{H}\right]$ thymidine incorporation studies additionally confirmed that forced overexpression of SM-20 abolished the antimitogenic effects of ANG II (Table 3). The inducer muristone (5 $\mu \mathrm{M}$ ) up-regulated SM-20 mRNA (Fig. 13B) as well as protein expression (Fig. 13C), even in the presence of $10^{-7}$ M ANG II.

\section{Discussion}

In contrast to AT1 receptors that are involved in growth stimulatory effects and extracellular matrix production, ANG II exerts antiproliferative actions through the AT2 receptor subtype (Gallinat et al, 2000). Depending on growth conditions, it has been also reported that AT2 receptor activation leads to apoptosis (Cao et al, 2000; Yamada et al, 1996). PC12 cells that exclusively express AT2 receptors are widely used to study potential effects of ANG II on the inhibition of proliferation and induction of differentiation, but other cells such as tubular cells with forced overexpression of AT2 receptors are also inhibited in proliferation after challenge with ANG II (Kambayashi et al, 1993; Leung et al, 1992; Meffert et al, 1996; Zimpelmann and Burns, 2001). Signal transduction pathways of the AT2 receptor are still not well understood, but involve certain lipid-signaling pathways, modification of tyrosine phosphatase activity, and induction of serine/threonine phosphatases (Gallinat et al, 1999; Steckelings et al, 1998).

Although is has been found that the antimitogenic effects of ANG II in PC12 cells are not mediated by repression of immediate early genes (Steckelings et al, 1998), potential target genes regulated by ANG ॥ through AT2 receptors are not known. Therefore, we used a differential display approach to identify such genes that may be potentially involved in ANG IIinduced growth suppression. We first confirmed previous data that ANG II reduces proliferation of PC12 cells grown either in the absence or presence of serum, and that these effects are mediated through AT2 receptors. The antimitogenic effect of ANG II may depend on activation of serine/threonine phosphatases because treatment with okadaic acid abolished the growth suppressive action of ANG II, whereas orthovanadate further reduced proliferation. The coupling of the AT2 receptor to serine/threonine phosphatases has been described in neuronal cells (Huang et 


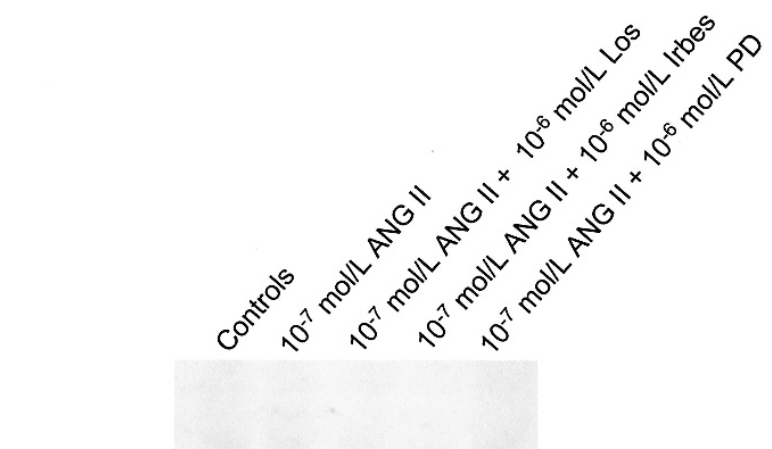

SM-20
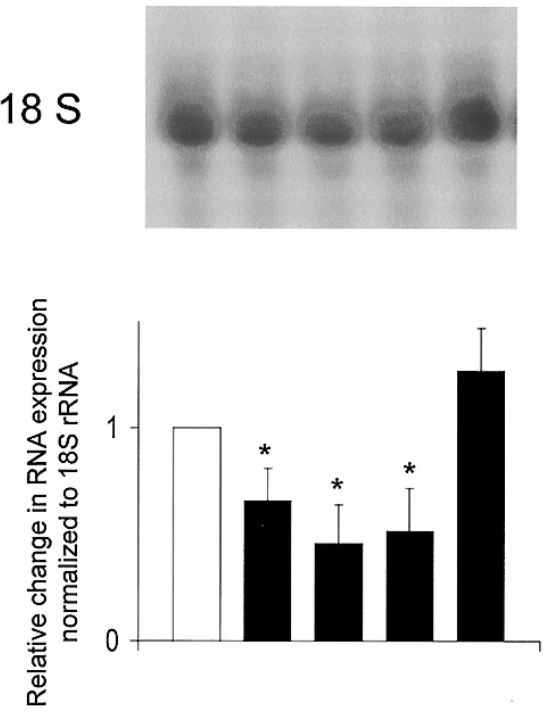

Figure 7.

SM-20 mRNA expression in rat glomerular endothelial cells that express both AT1 and AT2 receptors. Similar to PC12 cells, $10^{-7} \mathrm{M}$ ANG II for 6 hours significantly decreased SM-20 mRNA in rat glomerular endothelial cells. This effect was antagonized by the AT2 receptor antagonist, but not by the AT1 receptor blocker losartan (Los) or irbesartan (Irbes). These blots are representative of three independent experiments with qualitatively similar results.

al, 1995; Kang et al, 1994). Depending on the cell type and experimental conditions, ANG II mediates through AT2 receptors either an activation or inhibition of tyrosine phosphatases (Brechler et al, 1994; Kambayashi et al, 1993). Our data that orthovanadate inhibits proliferation could be interpreted that ANG IImediated inhibition of mitosis in PC12 cells depends on inhibition of tyrosine phosphatases. However, ANG II-mediated inhibition of proliferation in epithelial cells such as proximal tubular LLC-PK 1 cells transfected with AT2 receptors involves activation of tyrosine phosphatases (Zimpelmann and Burns, 2001).

We selected a stimulation time of 6 hours after ANG II treatment because we did not want to pick up very early expression products such as immediate early genes that are not influenced by ANG II in PC12 cells (Steckelings et al, 1998), but rather thought to identify later genes potentially involved in regulation of $G_{1} / S$ phase transit. Differential display analysis revealed that the majority of transcripts were reduced in PC12

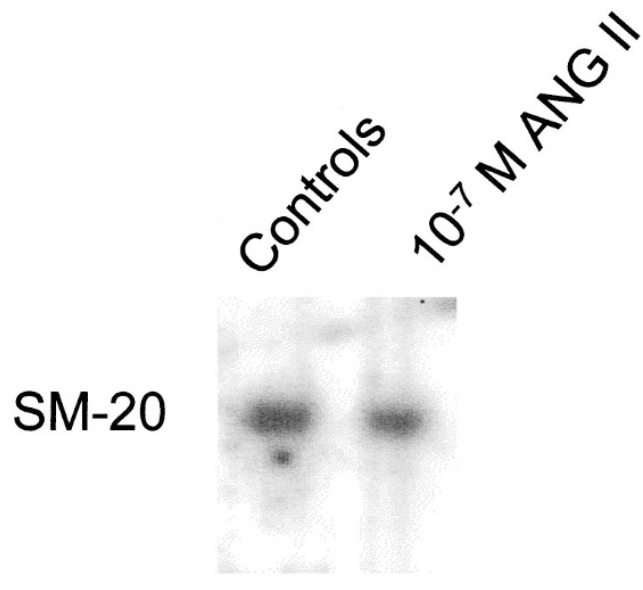

$18 \mathrm{~S}$

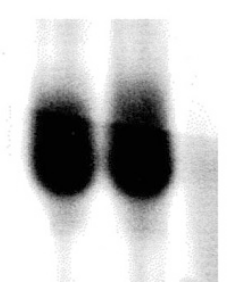

Figure 8.

Overexpression of AT2 receptors in COS7 cells that do not express ANG II-receptors. COS7 cells were transiently transfected with an AT2 receptor expression plasmid and incubated for 6 hours with $10^{-7} \mathrm{~m}$ ANG II. Northern blot analysis for SM-20 revealed that ANG II also leads to a down-regulation in these cells. These blots are representative of three independent experiments with qualitatively similar results.

cells after ANG II for 6 hours compared with unstimulated controls. One of these products is SM-20. This gene was originally isolated using differential screening of cDNA libraries derived from rat aortic smooth muscle cells stimulated with growth factors (Wax et al, 1994). More recently, a human SM-20 homolog has been cloned that is highly expressed in cardiac muscles and in the central nervous system (Dupuy et al, 2000). Growth factors such as serum and plateletderived growth factors induced SM-20 mRNA in quiescent vascular smooth muscle cells within 1 hour (Wax et al, 1994). The SM-20 transcripts were superinduced by cycloheximide (Wax et al, 1994). The open reading frame of SM-20 encodes a 355 amino acid protein with a molecular weight of $40 \mathrm{kd}$ (Wax et al, 1994, 1996). Like SM-20 transcripts, protein levels were also increased after serum stimulation of quiescent rat aortic smooth muscle cells (Wax et al, 1994). A high level of SM-20 expression in PC12 cells was already described in the original contribution, but the functional role remained at this time obscure (Wax et al, 1994). However, recent data provided novel insight into the function of SM-20 (Lipscomb et al, 1999, 2001). Sympathetic neurons are undergoing apoptosis when deprived of nerve growth factor. Differential display analysis revealed an up-regulation of SM-20 in these apoptotic neurons, suggesting a role of SM-20 in the process of apoptosis (Lipscomb et al, 1999). A 


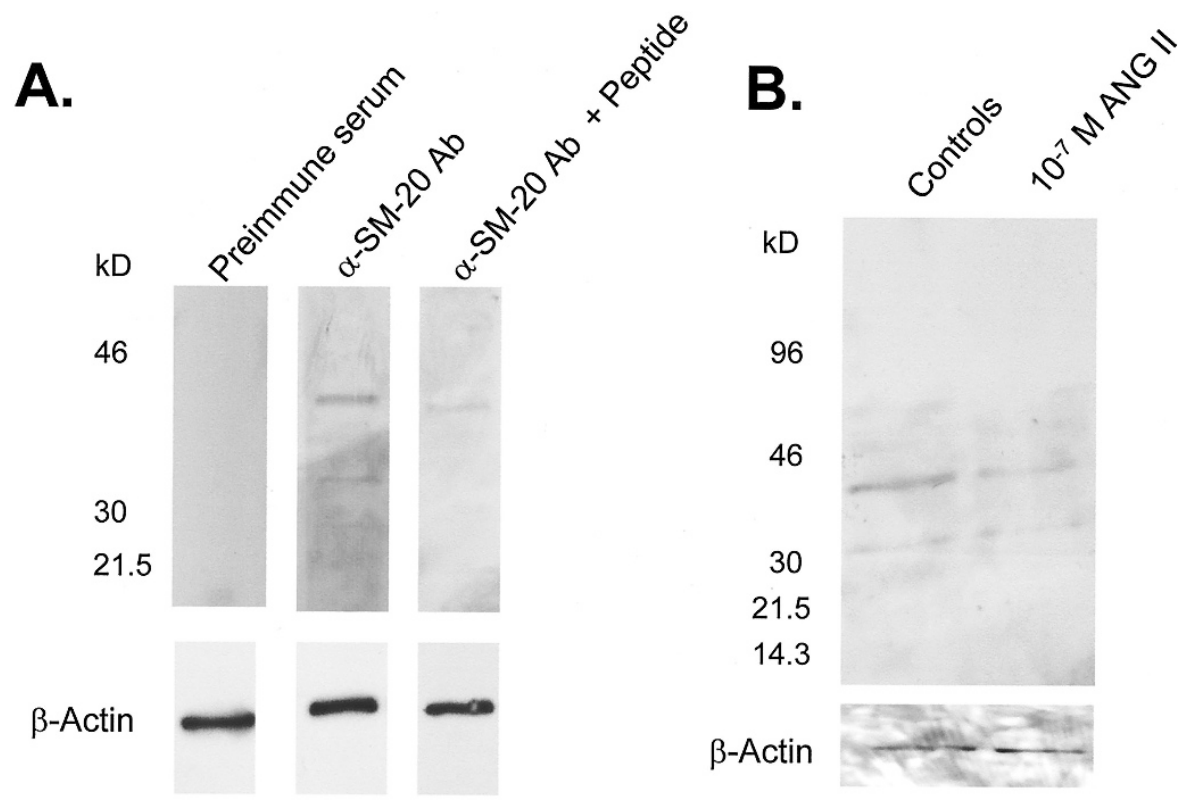

\section{Figure 9.}

Characterization of the anti-SM-20 antibody and SM-20 protein expression in PC12 cells. As described in "Materials and Methods," a rabbit polyclonal antibody was generated against peptide-encompassing amino acids 331-346 of SM-20 coupled to keyhole limpet hemocyanin. A, Preimmune serum obtained from the rabbit before immunization did not detect any band in PC12 cell lysates. The prepared polyclonal anti-SM-20 antibody ( $\alpha$-SM-20 Ab) recognized a stronger band of $40 \mathrm{kd}$ and a weaker band of approximately $33 \mathrm{kd}$. This smaller band has been previously described and is likely a processed form of SM-20 lacking amino-terminal sequences (Lipscomb et al, 2001). Preincubation of the antibody with $10 \mu \mathrm{g}$ of the peptide used for immunization almost completely abolished specific binding. These blots are representative of two independent experiments with similar results. B, Western blot analysis of total lysates of PC12 cells grown in serum-free medium (controls) or in the presence of $10^{-7} \mathrm{M}$ ANG II. Stimulation of PC12 cells with ANG II resulted in a decrease in SM-20 protein expression. All membranes were reprobed with a monoclonal antibody against $\beta$-actin to control for small variations in protein loading and transfer. This blot is representative of three independent experiments with qualitatively similar results.

recent study by Lipscomb and colleagues revealed that SM-20, at least in neurons, is a mitochondrial protein that promotes cell death through a caspase 3-dependent mechanism (Lipscomb et al, 2001). However, the function of SM-20 in this process may be more indirect because ectopic expression of SM-20 does not result in widespread Cyto $c$ release from mitochondria, a marker of apoptosis (Lipscomb et al, 2001).

Recently it has been found that SM-20 is a mammalian homolog to the EGL-9 gene of $C$. elegans (Epstein et al, 2001). EGL-9 is a dioxygenase that regulates hypoxia inducible factor 1 (HIF-1) by prolyl hydroxylation (Epstein et al, 2001). It seems that EGL-9 is an oxygen sensor and induction of this enzyme leads to prolyl hydroxylation of HIF with subsequent degradation of HIF-1 by a multiprotein complex with the von Hippel-Lindau tumorsuppressor protein as an important component (Epstein et al, 2001). HIF-1 is a transcription factor that activates a wide variety of target genes involved in growth and differentiation (Hofer et al, 2002). It has been shown that HIF-1 is expressed in normoxic conditions in many tissues, suggesting an important role in normal cell homeostasis (Strocka et al, 2001). Thus, one could speculate that ANG II may induce HIF-1 through down-regulation of SM-20. Indeed, ANG II-mediated HIF-1 expression has been described in vascular smooth muscle cells (Richard et al, 2000). We also have obtained preliminary evidence that ANG II up-regulates HIF-1 in PC12 cells (unpublished observation).

Our present data suggest that down-regulation of SM-20 expression is necessary for ANG II-mediated inhibition of proliferation, and induction of differentiation, of PC12 cells. Inhibition of SM-20 expression using antisense oligonucleotides mimicked the antimitogenic effects of ANG II, whereas forced inducible overexpression prevented ANG II-mediated inhibition of proliferation. The immunohistochemical staining of SM-20 in a punctuated pattern using our polyclonal antiserum is in agreement with the previously found mitochondrial compartmentalization (Lipscomb et al, 2001). In contrast to the previously reported expression in rat aortic vascular smooth muscle cells, we could not find an ANG II-induced increase in SM-20 transcripts using Northern blots in several cell lines such as mouse mesangial and tubular cells as well as tubular LLC-PK ${ }_{1}$ cells that exclusively express AT1 receptors. It seems that the robust base-line expression of SM-20 and down-regulation by ANG II depend on the presence of AT2 receptors as found in PC12 cells and GERs. The most direct evidence comes from our studies in COS7 cells with forced overexpression of AT2 receptors in which ANG II leads to suppression of SM-20 transcripts. Furthermore, the orthovanadateinduced down-regulation of SM-20 transcripts was associated with proliferation of PC12 cells, whereas okadaic acid antagonized ANG II-induced inhibition of proliferation and kept SM-20 expression high, even in 


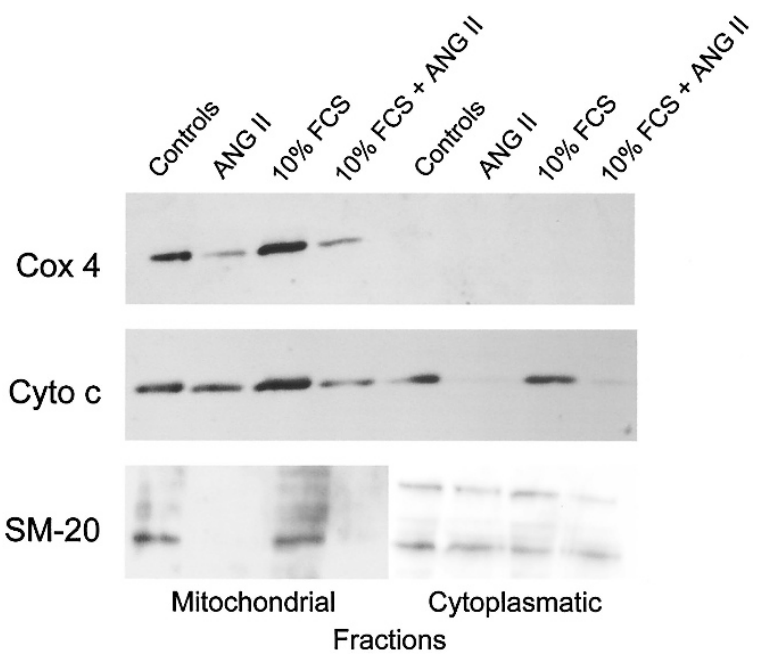

Figure 10.

Cell fractionation experiments. PC12 cells were stimulated for 24 hours as appropriate and mitochondrial fractions were enriched as described in "Materials and Methods." Mitochondrial and cytoplasmatic fractions were subjected to Western blotting. Mitochondrial-rich fractions were identified through expression of the inner mitochondrial membrane-associated protein cytochrome c oxidase subunit IV (Cox 4). Reincubation of the membrane with an antibody against cytochrome $\mathrm{c}$ (Cyto $c$ ) revealed strong expression in the mitochondrial fractions, but also some expression in cytoplasmatic fractions obtained from cells grown in the absence of ANG II. In contrast, stimulation with ANG II reduced Cyto c expression in the cytoplasmatic fractions. Western blotting of mitochondrial and cytoplasmatic fractions with the anti-SM-20 antiserum revealed only expression of the 33-kd band in mitochondrial fraction, whereas both bands are detectable in cytoplasmatic fraction. These blots are representative of two independent experiments (stimulation, fractionation, Western blotting) with qualitatively similar results.

the presence of ANG II. This reverse association of SM-20 expression and proliferation suggests that ANG II exerts its antimitogenic effects through AT2 receptorassociated activation of serine/threonine phosphatases that modulate SM-20 expression.

It has been suggested that ANG II principally exerts through AT1 and AT2 receptors opposite effects and a ying-yang hypothesis involving both receptors has been postulated (Gallinat et al, 2000). Our observations, together with previous data, may partly support this hypothesis. ANG II stimulates through AT1 receptors proliferation and also induces expression of SM-20 as previously reported in vascular smooth muscle cells (Wax et al, 1994). On the other hand, activation of AT2 receptors in PC12 cells inhibits proliferation, causes differentiation, and represses SM-20 expression.

We found in our current study that the antiproliferative effects of ANG II were not associated with induction of apoptosis. Moreover, ANG II-mediated downregulation of SM-20 in PC12 cells was rather associated with a reduced number of cells undergoing apoptosis as detected by translocalization of Cyto $\mathrm{C}$ into the cytoplasm. The observation that induced SM-20 expression is associated with apoptosis in neuronal cells fits this network (Lipscomb et al, 1999, 2001). Apoptosis is often associated with proliferation and requires in many systems active entrance into the cell cycle. In contrast, although its has been reported in some systems that activation of the AT2 receptor
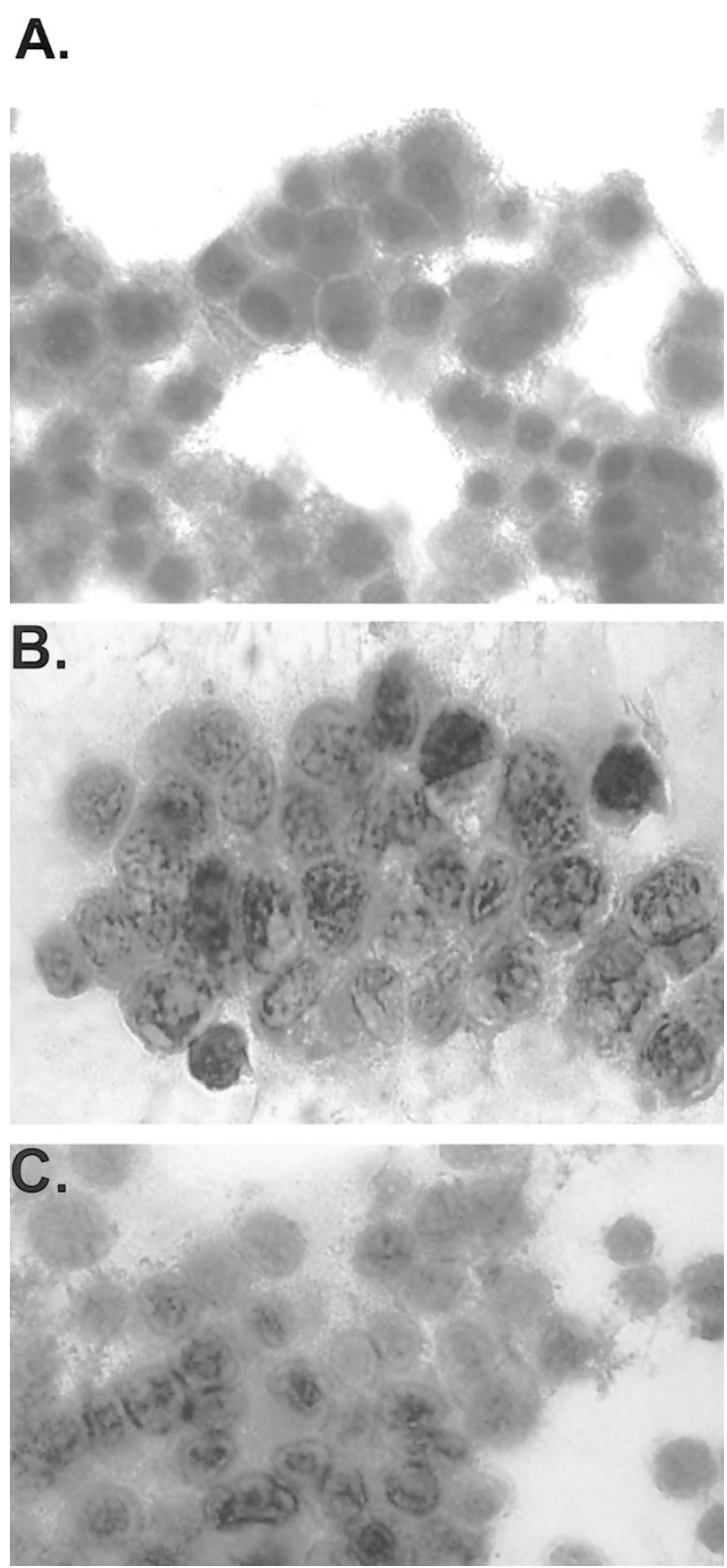

Figure 11.

Immunohistochemistry for SM-20 on acetone-fixed PC12 cells. A, Preimmune serum did not specifically stain PC12 cells. B, A granular cytoplasmatic staining is visible in cells grown in serum-free medium. C, There is a clear decrease in the overall number of positive cells as well as the staining intensity after $10^{-7} \mathrm{M}$ ANG II treatment.

after prolonged activation may cause apoptosis (Yamada et al, 1996), inhibition of proliferation does not necessary imply apoptosis, but could alternatively lead to cellular differentiation (Lucisu et al, 1998). Because it has been previously reported that the ANG II-mediated antimitogenic effects are associated with differentiation of PC12 cells (Meffert et al, 1996) and the AT2 receptor is also involved in axonal regeneration (Lucisu et al, 1998), these observations likely suggest cell cycle arrest and probably withdrawal from the cell cycle to induce differentiation. Although we have not formally quantitatively determined differentiation in our study, ANG II-treated PC12 cells 

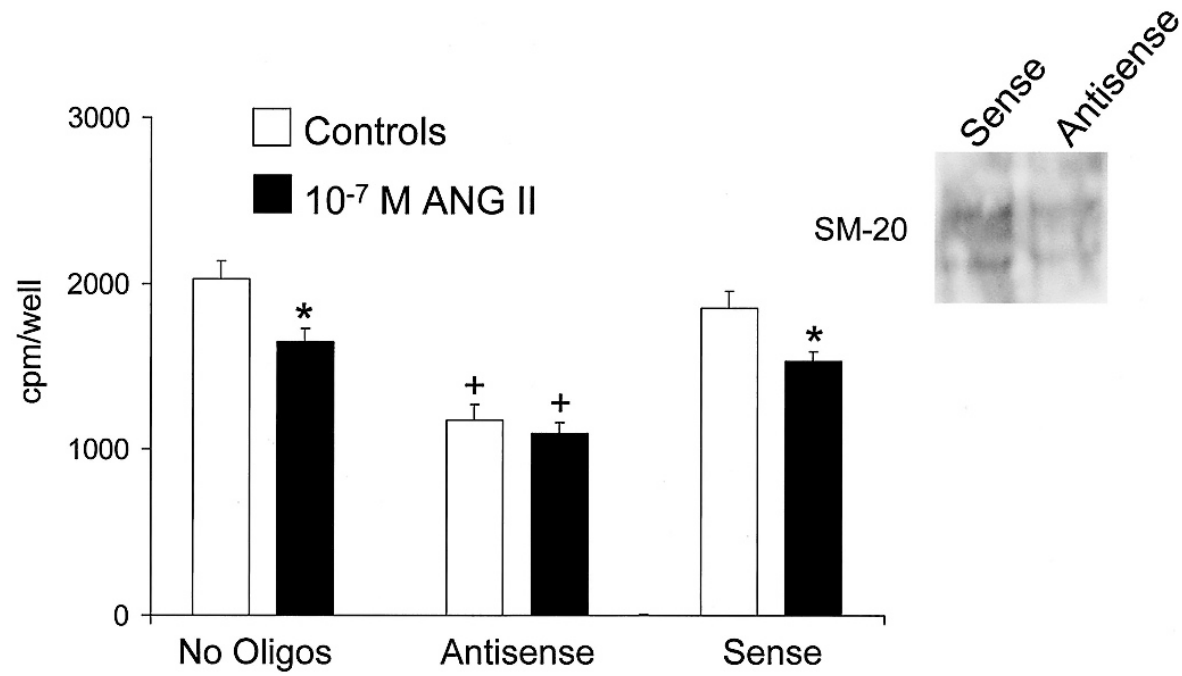

Figure 12.

Effect of SM-20 sense and antisense oligonucleotides on $\left[{ }^{3} \mathrm{H}\right]$ thymidine incorporation PC12 cells. ANG II $\left(10^{-7} \mathrm{M}\right)$ for 24 hours significantly reduced $\left[{ }^{3} \mathrm{H}\right]$ thymidine incorporation into PC12 cells grown in medium without serum. Transient transfection with $1 \mu \mathrm{m} \mathrm{SM-20} \mathrm{sense} \mathrm{oligonucleotides} \mathrm{did} \mathrm{not} \mathrm{influence} \mathrm{this} \mathrm{ANG} \mathrm{II-mediated}$ suppression of proliferation. However, SM-20 antisense oligonucleotides significantly reduced base-line $\left[{ }^{3} \mathrm{H}\right]$ thymidine incorporation. Addition of ANG II failed to further reduce proliferation in PC12 cells transfected with SM-20 antisense oligonucleotides. ${ }^{*} p<0.01$ versus controls, ${ }^{+}<p<0.01$ versus controls in the absence of oligonucleotides, $n=12$. Right insert, Transfection of cells with antisense but not sense oligonucleotides reduced SM-20 protein expression as detected by Western blotting.

A.

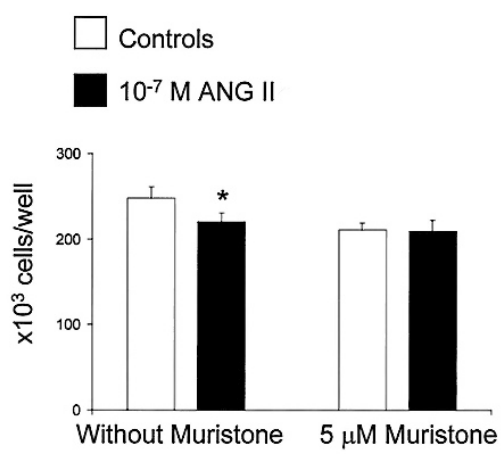

B.

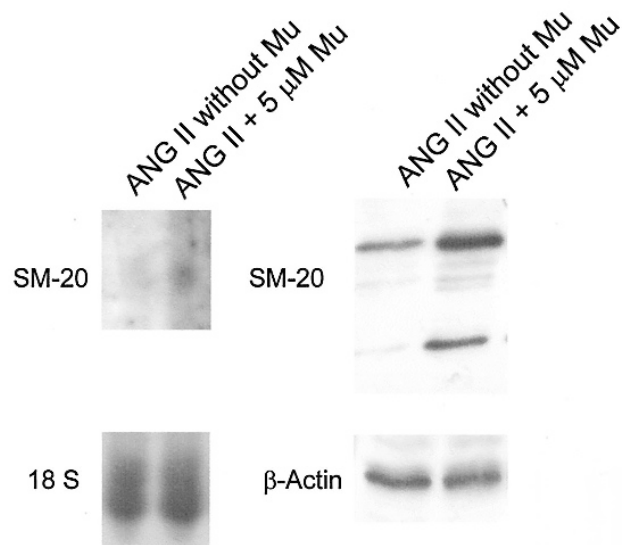

Figure 13.

A, Effect of inducible overexpression of SM-20 on PC12 cell number. ANG II induced a reduction of cell number in transiently transfected cells without the inducer muristone $(M u)$. However, after addition of $5 \mu \mathrm{m}$ muristone, ANG II failed to inhibit proliferation of PC12 cells. * $p<0.05$ versus controls, $n=12$. Muristone treatment led to up-regulation of SM-20 mRNA (B) and protein (C).

exhibited more neurite outgrowth, suggesting induction of differentiation (not shown). Apoptosis and proliferation are linked by cell cycle regulators, and apoptotic stimuli affects both proliferation and death (King and Cidlowski, 1998; Shankland and Wolf, 2000). For example, mesangial cell apoptosis was markedly increased in nephritic mice lacking the cyclindependent kinase (CDK)-inhibitor p27 ${ }^{\text {Kip1 }}$ (Ophascharoensuk et al, 1998). Moreover, apoptosis induced by growth factor deprivation or cycloheximide was strongly increased in p27 $7^{\mathrm{Kip} 1}$-/- mesangial in vitro compared with wild-type (Hiromura et al, 1999). Recently, it has also been suggested that death receptors are coupled to both cell proliferation and apopto- sis (Budd, 2002). In contrast, cellular differentiation requires up-regulation of CDK inhibitor and cell cycle arrest (Shankland and Wolf, 2000). In addition, inducible expression of $\mathrm{NF}-\kappa \mathrm{B}$-inducing kinase induces PC12 cell differentiation and concomitantly prevents apoptosis, suggesting that differentiation and apoptosis are oppositely regulated (Foehr et al, 2000). Thus, proliferation/apoptosis and differentiation may be viewed as contrary functions of a cell, requiring either active progression through the cell cycle or cell cycle exit. These functions are apparently associated with differential regulation of SM-20 expression. Assuming that SM-20 and HIF-1 expressions are inversely regulated, further studies are necessary to address how 
Table 3. Effect of Inducible SM-20 Overexpression on $\left[{ }^{3} \mathrm{H}\right]$ thymidine Incorporation in PC12 Cells Transiently Transfected with pINDSM-20/pVgRXR

\begin{tabular}{lc}
\hline & $\begin{array}{c}\text { Counts per minute } \\
\text { per well }\end{array}$ \\
\hline Controls without muristone & $3751 \pm 84$ \\
$10^{-7}$ M ANG II without muristone & $3500 \pm 92^{*}$ \\
Controls $+5 \mu \mathrm{M}$ muristone & $3173 \pm 65$ \\
$10^{-7}$ M ANG II $+5 \mu \mathrm{M}$ & $3312 \pm 83$ \\
$\quad$ muristone & \\
\hline
\end{tabular}

${ }^{*} p<0.05$ vs controls; $n=20$.

induction of HIF-1 mediates differentiation and how a decrease in HIF-1 promotes apoptosis.

\section{Materials and Methods}

\section{Cell Culture}

PC12 cells, a well-characterized rat adrenal pheochromocytoma cell line, were obtained from the European Collection of Animal Cell Cultures (Salisbury, United Kingdom). Cells were grown in suspension cultures in DMEM (Gibco-BRL, Eggenstein, Germany) with 10\% $\mathrm{FCS}$ in $5 \% \mathrm{CO}_{2}$ at $37^{\circ} \mathrm{C}$. In agreement with previous findings (Leung et al, 1992; Meffert et al, 1996), PC12 cells expressed only AT2-receptors by competitive binding assays (not shown).

GER is a previously characterized cell line that was established from glomerular endothelial cells derived from Wistar rats (Wolf et al, 1996b, 1997). These cells express AT1 and AT2 receptors (Wolf et al, 1996b, 1997). GERs were cultivated in DMEM with $10 \%$ FCS. Mouse mesangial cells and mouse proximal tubular cells are syngeneic cell lines originally established from SJL mice (Wolf and Neilson, 1990; Wolf et al, 1992). Mouse mesangial cells and mouse tubular cells have been extensively characterized and express only AT1-receptors. They were cultured in DMEM with $10 \%$ FCS and passaged every 3 to 4 days.

COS7 and LLC-PK 1 cells were also obtained from the European Collection of Animal Cell Cultures and cultured in DMEM with 10\% FCS. COS7 cells were transiently transfected with an expression vector in which a full-length rat AT2-receptor cDNA is under control of a CMV promoter (Zimpelmann and Burns, 2001; a gift of Dr. Kevin D. Burns, University of Ottawa, Ottawa, Canada). Transfection were performed with lipofectin (Gibco-BRL) as previously described (Wolf et al, 1996).

\section{Differential Display Analysis}

PC12 cells were rested in serum-free medium for 12 hours and were subsequently stimulated with a single dose of $10^{-7} \mathrm{M}$ human ANG II (Sigma, Deisenhofen, Germany) for another 6 hours. Control cells received only fresh serum-free medium. At the end of the incubation period, cells were washed in RNAse-free PBS and poly $(\mathrm{A})^{+}$RNA was isolated using the Fast Track kit (InVitrogen, Groningen, Netherlands). The
RNAimage kit (GeneHunter, Nashville, Tennessee) was used for differential display. Reverse transcription and subsequent PCR using degenerated anchored oligo(dT) primer was performed according to the manufacturer's recommendations. Ten microcuries of $\alpha-\left[{ }^{35} \mathrm{~S}\right] \mathrm{dATP}(2000 \mathrm{Ci} / \mathrm{mmole}$; Amersham, Braunschweig, Germany) were included in the PCR reactions and 40 cycles with an annealing temperature of $40^{\circ} \mathrm{C}$ for 2 minutes, an extension step at $72^{\circ} \mathrm{C}$ for 30 seconds, and a denaturation step at $92^{\circ} \mathrm{C}$ for 30 seconds were performed. Of the PCR product, $3.5 \mu \mathrm{l}$ was incubated in $2 \mu \mathrm{l}$ formamide loading buffer on a $6 \%$ denaturing polyacrylamide gel. Gels were vacuum dried, and autoradiograms were performed for 24 hours. After aligning the film with the gel, the DNA band of interest was cut out, boiled, and DNA was precipitated. DNA was reamplified using the same degenerated anchored oligo(dT) primer sets, and subcloned into the pGEM-T Easy vector (Promega, Madison, Wisconsin). Inserts were sequenced with the dideoxy method. GenBank was searched with BLAST for homologies to differentially expressed genes.

\section{Northern Blotting}

Quiescent PC12, GER, mouse mesangial cells, or mouse tubular cells were stimulated for different times (5 minutes to 24 hours) with various concentrations of ANG II $\left(10^{-10}\right.$ to $\left.10^{-4} \mathrm{M}\right)$ in the presence or absence of the AT1-receptor antagonist losartan $\left(10^{-6} \mathrm{M}\right.$; a gift of Merck, Sharp \& Dohme, Munich, Germany) or the AT2-blocker PD123319 (10 ${ }^{-6} \mathrm{M}$; Sigma). Additional cells were also treated with $10 \mu \mathrm{g} / \mathrm{ml}$ cycloheximide, $10^{-5} \mathrm{M}$ orthovanadate, or $10^{-7} \mathrm{M}$ okadaic acid (all from Calbiochem). After washing in RNAse-free PBS, cell were directly lysed in $4 \mathrm{M}$ guanidinium isothiocyanate, $25 \mathrm{~mm}$ sodium citrate ( $\mathrm{pH} 7.0), 0.6 \%$ sarcosyl, and 0.1 M 2-mercaptoethanol. Total RNA was isolated by repeated phenol-chloroform extractions and isopropanol precipitations. Twenty micrograms of total RNA were denatured by heating in formamide/formaldehyde at $65^{\circ} \mathrm{C}$ for 20 minutes and then subjected to electrophoresis through a $1.2 \%$ agarose gel containing $2.2 \mathrm{M}$ formaldehyde. The RNA was then vacuum blotted onto nylon membranes (Hybond-N; Amersham), and filters were ultraviolet cross-linked. The 261 cDNA insert of the differential display cloned being identical to SM-20 was used as a probe. Alternatively, a 1.1-kb EcoRI-EcoRV cDNA fragment from pDS12 encoding full-length rat SM-20 (Lipscomb et al, 2001) was also used for experiments and revealed identical results. The cDNA inserts were labeled with $\left[{ }^{32} \mathrm{P}\right] \mathrm{dATP}$ (3000 Ci/mmol; Amersham) using hexamer primers. Prehybridization, hybridization, washes, and autoradiography were performed as previously described in detail (Wolf et al, 1997). To control for small variations in RNA loading and transfer, stripped filters were rehybridized with a 2.0-kb cDNA insert of the plasmid $\mathrm{pMCl}$ encoding the murine $18 \mathrm{~S}$ band. Exposed films were scanned with Fluor-S multi-imager (Bio-Rad, Hercules, California), and data were analyzed with the computer program MultiAnalyst (Bio- 
Rad). A ratio between the intensities of SM-20 and 18 $\mathrm{S}$ bands was calculated and control cells were arbitrarily assigned a relative value of 1.00 .

\section{Measurement of Proliferation}

Proliferation was assessed by direct counting of cells. For these experiments, $10^{5}$ cells were seeded into each well of a 24-well plate. After incubation for 12 hours in serum-free medium, cells were further incubated for 24 to 72 hours with ANG II in the presence or absence of $10 \%$ FCS. Some cells also received either AT1- or AT2-receptor antagonists. Additional cells were treated with $10^{-7} \mathrm{M}$ okadaic acid or $10^{-5} \mathrm{M}$ orthovanadate in the presence or absence of ANG II. After incubation as appropriate, cells were scraped off the plate with a rubber policeman and were washed twice in PBS. An aliquot of cells was counted in a Fuchs-Rosenthal chamber after resuspension of cells in PBS.

In addition, incorporation of $\left[{ }^{3} \mathrm{H}\right]$ thymidine into DNA was used as another measurement of proliferation. Cells $\left(10^{4}\right.$ cells per well) were transferred to a 96-well microtiter plate, and made quiescent by incubation in serum-free medium for 12 hours. Cells were stimulated as indicated for 24 hours and were pulsed with 1 $\mu \mathrm{Ci}\left[{ }^{3} \mathrm{H}\right]$ thymidine $(5 \mathrm{Ci} / \mathrm{mmol}$, Amersham) during the last 6 hours of culture. At the end of the incubation period, cells were collected on glass-fiber paper with an automatic cell harvester (Wolf et al, 1997). Radioactivity of dry filters was measured by liquid scintillation spectroscopy.

\section{Determination of Apoptosis}

Detection of internucleosomal DNA fragmentation was used to test whether ANG II induces apoptosis in PC12 cells. Cells were stimulated for 24 hours with $10^{-7} \mathrm{M}$ ANG II in the absence or presence of $10 \%$ FCS. DNA extraction was performed with a DNA laddering kit (R\&D Systems, Wiesbaden, Germany) according to the manufacturer's recommendations. DNA samples were loaded onto a $1 \%$ agarose gel and the gel was stained after electrophoresis with 0.5 $\mu \mathrm{g} / \mathrm{ml}$ ethidium bromide to detect DNA. These experiments were independently performed three times with similar results. PC12 cells treated with $50 \mu \mathrm{M}$ etoposide (Sigma) served in one experiment as a positive control for apoptosis (not shown).

\section{Generation and Characterization of Polyclonal Anti-SM-20 Antibody, Western Blots, Cell Fractionation, and Immunohistochemistry}

A modified peptide encompassing amino acid sequence 331-346 of SM-20 (CERAEAKKKFRNLTR) was coupled with the $\mathrm{N}$-terminal cysteine residue to keyhole limpet hemocyanin (Biotrend, Cologne, Germany). New Zealand white rabbits were immunized and subsequently boostered three times. After bleeding, IgG was isolated with affinity chromatography.

For Western blot experiments, $10^{6} \mathrm{PC} 12$ cells were treated for 6 hours with $10^{-7} \mathrm{M}$ ANG II. After washing in PBS, cells were lysed in 2\% SDS, $60 \mathrm{~mm}$ Tris- $\mathrm{HCl}$ (pH 6.8), $100 \mathrm{~mm}$ dithiothreitol, and the protein content was measured by a modification of the Lowry method that is insensitive to the used concentrations of SDS and dithiothreitol. Protein concentrations were adjusted to $80 \mu \mathrm{g} / \mathrm{sample}, 5 \%$ glycerol, $0.03 \%$ bromophenol blue were added, and samples were boiled for 5 minutes. After centrifugation, supernatants were loaded onto a denaturing 10\% SDS-polyacrylamide gel. Rainbow markers (Amersham) served as molecular weight standards. After completion of electrophoresis, proteins were electroblotted onto a nitrocellulose membrane in transfer buffer $(50 \mathrm{~mm}$ Tris- $\mathrm{HCl}$, $\mathrm{pH} 7.0,30 \mathrm{~mm}$ glycine, 20\% methanol, 0.1\% SDS). Filters were stained with Ponceau S (Sigma) to control for equal loading and transfer. The blots were blocked in $8 \%$ nonfat dry milk in PBS with $0.1 \%$ Tween for 1 hour at room temperature. The anti-SM-20 antibody was used in a 1:200 dilution. The secondary goat anti-rabbit IgG peroxidase-conjugated antibody (BD Bioscience, Heidelberg, Germany) was used in a 1:1000 dilution. The ECL system (Amersham) was used for luminescence detection. To detect for small variations in protein loading and transfer, the membranes were washed and reincubated with a monoclonal antibody against the housekeeping protein $\beta$-actin (Sigma). Bands were scanned and analyzed by densitometry. An intensity ratio of SM-20 and $\beta$-actin bands was calculated. Western blotting experiments were independently performed three times with qualitatively similar results. For control experiments, the SM-20 antibody was replaced by preimmune serum from exactly the same rabbit used subsequently for immunization. As an additional control, the SM-20 antibody was preincubated for 30 minutes at room temperature with $10 \mu \mathrm{g}$ of the modified peptide used for immunization. This preincubated antibody was then used for the detection of SM-20 protein in PC12 cell lysates.

To obtain information on which cellular structures express SM-20, cell fractionation experiments were performed using the ApoAlert cell fractionation kit (Clontech, Palo Alto, California). Mitochondrial and cytoplasmatic fractions were identified after Western blotting with an antibody against Cox 4 that is exclusively expressed in the inner mitochondrial membrane. Blots were washed and subsequently reincubated with either the SM-20 antiserum or an antibody against Cyto c, a protein released early into the cytoplasm during apoptosis. Cell fractionation experiments with Western blots were independently performed twice with qualitatively similar results.

For immunohistochemistry detection of SM-20, cells were stimulated as appropriate, washed in PBS, and pipetted on glass slides covered with gelatin. After air drying, cells were fixed in ice-cold acetone for 5 minutes. Slides were incubated with a 1:2 dilution of the polyclonal anti-SM-20 antibody or undiluted preimmune rabbit serum as negative control. Endogenous peroxidase was blocked with $0.3 \% \mathrm{H}_{2} \mathrm{O}_{2}$ in PBS for 30 minutes. Peroxidase-conjugated goat antirabbit IgG antibody (Santa Cruz Biotechnology, Santa 
Cruz, California) was used as a secondary antibody in a 1:30 dilution. Peroxidase activity was detected with diaminobenzidine.

\section{Inhibition of SM-20 Expression with Antisense Oligonucleotides and Overexpression Using Ecdysone-Inducible Vectors}

To investigate the function of SM-20, expression was inhibited using antisense technology. PC12 were transfected with $1 \mu \mathrm{M}$ of either phosphothioatemodified sense (5'ACCATGACGTTGAGGTCAA3') or antisense (5'TTGACCTCAACGTCATGGT3') oligonucleotides using lipofectin as described (Wolf et al, 1996a). After 12 hours, cells were replated into a 96-well plate, stimulated with ANG II for 24 hours, and $\left[{ }^{3} \mathrm{H}\right]$ thymidine incorporation was measured as described above. PC12 cells in small tissue flasks were also transfected with either sense or antisense oligonucleotides. After 24 hours, cells were lysed, and Western blots were performed with the anti-SM-20 antibody to test the effect of sense and antisense oligonucleotides on SM-20 protein expression. Blots were performed independently twice with qualitatively similar results.

To overexpress SM-20, the full-length rat SM-20 cDNA was subcloned into pIND (InVitrogen; No et al, 1996). Cells were co-transfected with $10 \mu \mathrm{g}$ of pINDSM-20 and pVgRXR that expresses the heterodimeric ecdysone receptor. Induction of SM-20 transcription was achieved by incubation with $5 \mu \mathrm{M}$ muristone (InVitrogen) as previously described (Wolf et al, 2001). This inducible expression system has the advantage that mammalian cells do not contain the ecdysone receptor (No et al, 1996). Therefore, basal levels of transcription are very low and this system does not interfere with cell cycle regulation in mammalian cells. Furthermore, uninduced control cells are transfected with the some vector system. After 12 hours, cells were replated into 24- or 96-well plates. Proliferation was measured by $\left[{ }^{3} \mathrm{H}\right]$ thymidine incorporation (96-well plates) or counting total cells (24-well plates) in the presence and absence of ANG II and muristone. Expression of SM-20 mRNA and protein was determined by Northern and Western blots as described above.

\section{Statistical Analysis}

All values are presented as means \pm SEM. Statistical significance among multiple groups was first tested with the nonparametric Kruskal-Wallis test. Individual groups were then tested using the Wilcoxon-MannWhitney test. A $p$ value of $<0.05$ was considered significant.

\section{Acknowledgements}

We thank Dr. Kevin D. Burns, Department of Medicine, University of Ottawa, Canada, for the AT2 receptor expression plasmid. Parts of this study were presented at the annual meeting of the American Society of Nephrology (October 10-16, 2000, Toronto, Cana- da), and Hypertension 2000 (November 22-25, 2000, Heidelberg, Germany). This study has been published in abstract form (J Am Soc Nephrol 11:467A, 2000; and Nieren- und Hochdruckkrankheiten 30:196-197, 2001).

\section{References}

Brechler V, Reichlin S, de Gasparo M, and Bottari SP (1994). Angiotensin II stimulates protein tyrosine phosphatase activity through a G-protein independent mechanism. Receptors Channels 2:89-87.

Budd RC (2002). Death receptors couple to both cell proliferation and apoptosis. J Clin Invest 109:437-441.

Cao Z, Kelly DJ, Cox A, Casley D, Forbes JM, Martinello P, Dean R, Gilbert RE, and Cooper ME (2000). Angiotensin type 2 receptor is expressed in the adult rat kidney and promotes cellular proliferation and apoptosis. Kidney Int 58:2437-2451.

Dupuy D, Aubert I, Dupérat VG, Petit J, Taine L, Stef M, Bloch B, and Arveiler B (2000). Mapping, characterization, and expression analysis of the SM-20 human homologue, C1orf12, and identification of a novel related gene, SCAND2. Genomics 69:348-354.

Epstein ACR, Gleadle JM, McNeill LA, Hewitson KS, O'Rourke J, Mole DR, Mukherji M, Metzen E, Wilson MI, Dhanda A, Tian YM, Masson N, Hamilton DL, Jaakkola P, Barstead R, Hodgkin J, Maxwell PH, Pugh CW, Schofield PH, and Ratcliff P (2001). C. elegans EGL-9 and mammalian homologs define a family of dioxygenases that regulate HIF by prolyl hydroxylation. Cell 107:43-54.

Foehr ED, Bohuslav J, Chen LF, DeNoronha C, Geleziunas R, Lin X, O'Mahony A, and Greene WC (2000). The NF- $\kappa$ Binducing kinase induces PC12 cell differentiation and prevents apoptosis. J Biol Chem 275:34021-34024.

Gallinat S, Busche S, Raizada MK, and Sumners C (2000). The angiotensin II type 2 receptor: An enigma with multiple variations. Am J Physiol 278:E357-E374.

Gallinat S, Busche S, Schütze S, Krönke M, and Unger T (1999). AT 2 receptor stimulation induces generation of ceramides in PC12W cells. FEBS Lett 443:75-79.

Hiromura K, Pippin JW, Fero ML, Roberts JM, and Shankland SJ (1999). Modulation of apoptosis by the cyclin-dependent kinase inhibitor p27 ${ }^{\text {Kip1 }}$. J Clin Invest 103:597-604.

Hofer T, Wenger RH, and Gassmann M (2002). Oxygen sensing, HIF-1 $\alpha$ stabilization and potential therapeutic strategies. Eur J Physiol 443:503-507.

Huang XC, Richards EM, and Sumners C (1995). Angiotensin II type 2 receptor-mediated stimulation of protein phosphatase $2 \mathrm{~A}$ in rat hypothalamic/brainstem neuronal cocultures. J Neurochem 65:2131-2137.

Kambayashi Y, Bardhan S, Takahashi K, Tsuzuki S, Inui H, Hamakubo T, and Inagami T (1993). Molecular cloning of a novel angiotensin II receptor isoform involved in phosphotyrosine phosphatase inhibition. J Biol Chem 268:2454324546.

Kang J, Posner P, and Sumners C (1994). Angiotensin II type 2 receptor stimulation of neuronal $\mathrm{K}^{+}$currents involves and inhibitory GTP binding protein. Am J Physiol 267:C1389C1397.

Katz AM (1990). Angiotensin II: Hemodynamic regulator or growth factor? J Mol Cell Cardiol 22:739-747. 
King KL and Cidlowski JA (1998). Cell cycle regulation and apoptosis. Annu Rev Physiol 60:601-617.

Leung $\mathrm{KH}$, Roscoe WA, Smith RD, Timmermans PBM, and Chiu AT (1992). Characterization of biochemical responses of angiotensin II $\left(\mathrm{AT}_{2}\right)$ binding sites in the rat pheochromocytoma PC12W cells. Eur J Pharmacol 227:63-70.

Lipscomb EA, Sarmiere PD, Crowder RJ, and Freeman RS (1999). Expression of the SM-20 gene promotes death in nerve growth factor-dependent sympathetic neurons. J Neurochem 73:429-432.

Lipscomb EA, Sarmiere PD, and Freeman RS (2001). SM-20 is a novel mitochondrial protein that causes caspasedependent cell death in nerve growth factor-dependent neurons. J Biol Chem 276:5085-5092.

Lucisu R, Gallinat S, Rosenstiel P, Herdegen T, Stevers J, and Unger $\mathrm{T}$ (1998). The angiotensin II type $2\left(\mathrm{AT}_{2}\right)$ receptor promotes axonal regeneration in the optic nerve of adult rats. J Exp Med 188:661-670.

Matsubara H (1998). Pathophysiological role of angiotensin II type 2 receptor in cardiovascular and renal disease. Circ Res 83:1182-1191.

Meffert S, Stoll M, Steckelings UM, Bottari SP, and Unger T (1996). The angiotensin II $A T_{2}$ receptor inhibits proliferation and promotes differentiation in PC12W cells. Mol Cell Endocrinol 122:59-67.

No D, Yao TP, and Evans RM (1996). Ecdysone-inducible gene expression in mammalian cells and transgenic mice. Proc Natl Acad Sci USA 93:3346-3351.

Ophascharoensuk V, Fero ML, Hughes J, Roberts JM, and Shankland SJ (1998). The cyclin kinase inhibitor p27 Kip1 safeguards against inflammatory injury. Nat Med 4:575-580.

Richard DE, Berra E, and Pouysségur J (2000). Nonhypoxic pathway mediates the induction of hypoxia-inducible factor $1 \alpha$ in vascular smooth muscle cells. J Biol Chem 275:2676526771.

Shankland SJ and Wolf G (2000). Cell cycle regulatory proteins in renal disease: Role in hypertrophy, proliferation, and apoptosis. Am J Physiol 278:F515-F529.

Steckelings UM, Bottari SP, Stoll M, Wagner J, and Unger T (1998). Repression of c-fos and c-jun gene expression is not part of $\mathrm{AT}_{2}$ receptor coupled signal transduction. $\mathrm{J} \mathrm{Mol} \mathrm{Med}$ 76:202-207.

Stoll M, Steckeling UM, Paul M, Bottari SP, Metzger R, and Unger T (1995). The angiotensin AT2-receptor mediates inhibition of cell proliferation in coronary endothelial cells. J Clin Invest 95:651-657.

Strocka DM, Burkhardt T, Desbaillets I, Wenger RH, Neil DAH, Bauer C, Gassmann M, and Candinas D (2001). HIF-1 is expressed in normoxic tissue and displays an organspecific regulation under systemic hypoxia. FASEB J 15: 2445-2453.
Wax SD, Rosenfield CL, and Taubman MB (1994). Identification of a novel growth factor-responsive gene in vascular smooth muscle cells. J Biol Chem 269:13041-13047.

Wax SD, Tsao L, Lieb ME, Fallon JT, and Taubman MB (1996). SM-20 is a novel 40-kd protein whose expression in the arterial wall is restricted to smooth muscle. Lab Invest 74:797-808.

Wolf $G$ and Neilson EG (1990). Angiotensin II induces cellular hypertrophy in cultured murine proximal tubular cells. Am J Physiol 259:F768-F777.

Wolf G and Neilson EG (1993). Angiotensin II as a renal growth factor. J Am Soc Nephrol 3:1531-1540.

Wolf G, Haberstroh U, and Neilson EG (1992). Angiotensin II stimulates the proliferation and biosynthesis of type I collagen in cultured murine mesangial cells. Am J Pathol 140:95107.

Wolf G, Schroeder R, Zahner G, Stahl RAK, and Shankland SJ (2001). High glucose-induced hypertrophy of mesangial cells requires $\mathrm{p} 27^{\mathrm{Kip} 1}$, an inhibitor of cyclin-dependent kinases. Am J Pathol 158:1091-1100.

Wolf G, Zahner G, Schroeder R, and Stahl RAK (1996a). Transforming growth factor beta mediates the angiotensin II-induced stimulation of collagen type IV synthesis in cultured murine proximal tubular cells. Nephrol Dial Transplant 11:263-269.

Wolf G, Ziyadeh FN, Thaiss F, Tomaszewski J, Caron RJ, Wenzel U, Zahner G, Helmchen U, and Stahl RAK (1997). Angiotensin II stimulates expression of the chemokine RANTES in rat glomerular endothelial cells. J Clin Invest 100: 1047-1058.

Wolf G, Ziyadeh FN, Zahner G, and Stahl RAK (1996b). Angiotensin II is mitogenic for cultured rat glomerular endothelial cells. Hypertension 27:897-905

Woolfson RG and Fine LG (1996). The influence of vasoactive factors on renal cell growth. J Nephrol 9:49-57.

Yamada T, Horiuchi M, and Dzau VJ (1996). Angiotensin II type 2 receptor mediates programmed cell death. Proc Natl Acad Sci USA 93:156-160.

Zimpelmann $\mathrm{J}$ and Burns KD (2001). Angiotensin II $A T_{2}$ receptors inhibit growth responses in proximal tubule cells. Am J Physiol 281:F300-F308. 